\title{
Bioadsorbent based on water hyacinth modified with citric acid for adsorption of methylene blue in water
}

\author{
Eko Siswoyo ${ }^{1, *}$, Anandhitya Rhezsa Adrian ${ }^{1}$, and Shunitz Tanaka ${ }^{2}$ \\ ${ }^{1}$ Environmental Engineering Program, Faculty of Civil Engineering and Planning, Islamic University of Indonesia (UII), J1. Kaliurang \\ Km 14.5 Yogyakarta 55584, Indonesia \\ ${ }^{2}$ Graduate School of Environmental Science, Hokkaido University, Sapporo Kitaku North 10 West 5, Hokkaido 060-0810, Japan
}

\begin{abstract}
Recently, textile wastewater contamination has been a common problem in Indonesia because many textile industries disposed their wastewater directly to the river without proper treatment. The purpose of this study was to investigate the ability of a low-cost adsorbent based on water hyacinth. The adsorbent is prepared from water hyacinth powder (WHP) and water hyacinth modified with citric acid (WHMCA) for removal of dyes methylene blue (MB) in water. In order to know the properties of the adsorbent, WHP and WHMCA were characterized by FTIR and SEM, respectively. The effect of dose of adsorbent $(10-100 \mathrm{mg})$, $\mathrm{pH}$ condition $(2-10)$, contact time $(30 \mathrm{~min}-24 \mathrm{~h})$ and initial concentration of methylene blue $(100-600$ $\mathrm{mg} / \mathrm{L}$ ) were investigated. Based on Langmuir isotherm adsorption model, it was found that the adsorption capacity of the adsorbent before and after modification with citric acid for MB was $261 \mathrm{mg} / \mathrm{g}$ and $320 \mathrm{mg} / \mathrm{g}$, respectively and the optimum contact time was $2 \mathrm{~h}$. The finding of the present study proved that WHMCA should be considered as a promising adsorbent in the near future.
\end{abstract}

\section{Introduction}

In the recent year, textile industries grow very fast, especially for some cities in Indonesia which known as batik industry. Indonesia has many textile industries from micro-scale to macro-scale, and each industry produces textile wastewater consisting of various dyes. This problem will not be solved in short period, because of increasing demand is always followed by the increase in production. There are many ways to treat textile wastewater, however, high cost and limit of technology make producers ignore to treat their wastewater. Disposal of wastewater containing dyes compounds into water sources has caused serious environmental impact because dyeing effluent will deplete the dissolved oxygen content in water, inhibit sunlight from reaching to the water sources and also contaminate the living organism in the water [1].

In this study, a low-cost adsorbent was developed based on Water hyacinth to adsorb one of the basic dyes, methylene blue (MB) in water. In recent years, there is only few researcher concerning on adsorption with water hyacinth. In many places, it is very easy to find water hyacinth and people usually assume that water hyacinth is a disturber plant, therefore it is just usually disposed of as waste. There are some studies on the using of water hyacinth as an adsorbent, such as to adsorb copper [2], oil [3] and ammonia [4].

In the present study, water hyacinth will be modified with citric acid. Cellulose cell in water hyacinth will bind carboxyl groups of the citric acid. The low-cost citric acid has been used as a modification agent in order to attach free carboxyl groups onto the hydroxyl of polysaccharide matrix of cellulosic waste materials [8].

In this present research, the water hyacinth was modified with citric acid in order to improve its adsorption capacity for cationic dyes [1]. Water hyacinth was dried and crushed into powder, named water hyacinth powder (WHP). After that WHP was modified by citric acid, named water hyacinth modified citric acid (WHMCA). By this modification, some functional groups of citric acid such as carboxylic acid is expected can increase the adsorption capacity of the adsorbent [5], [9] and [10].

In this study, WHMCA is used for treat methylene blue. Further, WHMCA can be used for treat others pollutant which has positive charge. The negative charge of WHMCA can be used to attract cationic particles. It is possible that WHMCA can treat heavy metal which has positive charge because WHMCA has carboxyl groups.

\section{Materials and Methods}

\subsection{Preparation of adsorbent}

Water hyacinth was dried and crushed into powder, named water hyacinth powder (WHP). Then, WHP was soaked into 1,3 $\mathrm{M}$ citric acid solution (4 $\mathrm{ml}$ citric acid for $1 \mathrm{~g} \mathrm{WHP}$ ) and stirred for $2 \mathrm{~h}$ following [5]. The slurry was dried in oven for $24 \mathrm{~h}$. After that, it was dried on $150^{\circ} \mathrm{C}$ by using a furnace for 30 minutes, neutralized with

* Corresponding author: eko_siswoyo@uii.ac.id 
distilled water and $\mathrm{NaOH}$ until $\mathrm{pH}$ becomes 7. After neutralization, the slurry was dried for $24 \mathrm{~h}$ and crushed into powder, named water hyacinth modified by citric acid (WHMCA).

WHMCA was characterized by FTIR to know the amount of the functional groups and to know the modified was successfully conducted or not. Beside FTIR, WHMCA was also characterized by SEM to know the visualization of the pore and the surface of the adsorbent.

\subsection{Process of adsorption}

The effect of dosage of the adsorbent, $\mathrm{pH}$ condition, contact time and initial concentration of methylene blue was investigated in this section. Firstly, the various dosage is done to obtain the optimum amount of adsorbent. Various 10, 25, 50, 75 and $100 \mathrm{mg}$ of WHMCA was tried to adsorb $500 \mathrm{ppm}$ methylene blue in $\mathrm{pH} 6$ with 2 hours contact time. Second, various $\mathrm{pH}$ condition (2, 4, 6,8 , and 10) was studied to adsorb $500 \mathrm{ppm}$ of methylene with the optimum dosage in $\mathrm{pH} 6$ and 2 hours contact time.

Third, various of contact time from $30 \mathrm{~min}, 1$ hour, 2 hours, 4 hours, 6 hours, 15 hours, 18 hours and 24 hours was tried to adsorb $500 \mathrm{ppm}$ of methylene blue with optimum dosage and optimum $\mathrm{pH}$ condition. Finally, several kinds of initial concentration of methylene blue were investigated in order to get the maximum adsorption capacity. The initial concentrations of methylene blue were $100,200,300,400,500$ and $600 \mathrm{ppm}$. The spectrophotometer devices were utilized with $665 \mathrm{~nm}$ in order to know the concentration of methylene blue in the water.

\section{Results and Discussion}

\subsection{Properties of adsorbent}

The result of SEM image of the adsorbents is shown in Figure 3.1. It is very difficult to identify the effect of citric acid activation on adsorbent by using SEM image, however, it can be seen from the figure that surface area of the adsorbent is probably higher after activation process.

In order to know the presence of functional groups in the adsorbent, FTIR analysis was utilized and the result is shown in Figure 3.2. WHMCA and WHP were analyzed by FTIR, Jasco FT/IR-4100, and SEM, JEOL JSM-636OLA. The FTIR spectra indicate that there are new functional groups in WHMCA. There are two new peaks in $1717 \mathrm{~cm}-1$ and $1620 \mathrm{~cm}-1$, this data shows that carboxyl groups appear after modification and indication that the modification has succeed. Different with FTIR spectra, the result of SEM analysis cannot be analyzed because of the irregular form of the adsorbent. This condition makes the adsorbent cannot be compared withother adsorbents.

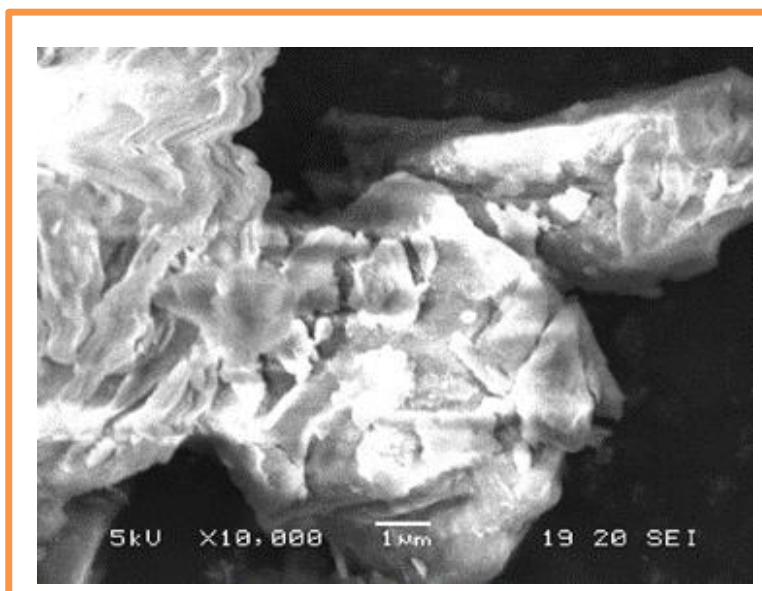

(A)

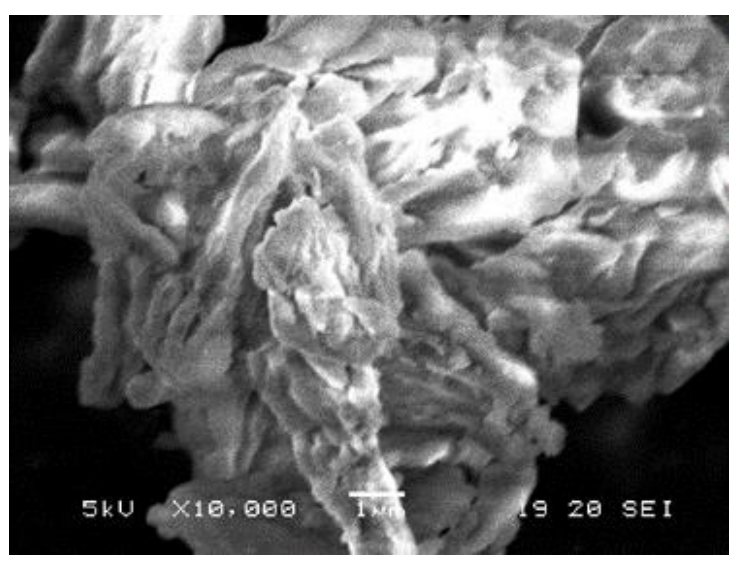

(B)

Figure 3.1 SEM image of adsorbent (A. WHP and B. WHMCA)

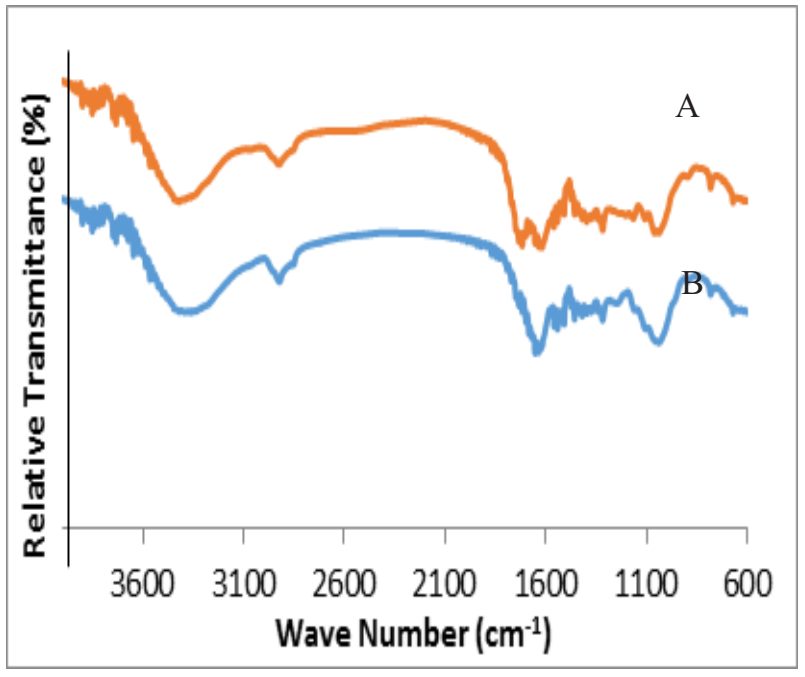

Figure 3.2 FTIR spectra of adsorbents (A) WHMCA and (B) WHP 


\subsection{Effect of adsorbent mass on the adsorption of methylene blue}

Effect of adsorbent dosage was studied to find out the optimum adsorption capacity for the further experimental test. The removal rate of methylene blue is shown in Fig. 3.3. It was clear that removal rate increased for both initial concentrations ( 250 and $500 \mathrm{ppm}$ ) from 10 to $50 \mathrm{mg}$. After $50 \mathrm{mg}$ of adsorbent, there are no changes in removal rate. Moreover, WHMCA has high capability to remove methylene blue because it has $94 \%$ of removal for 500 ppm initial concentration of methylene blue.

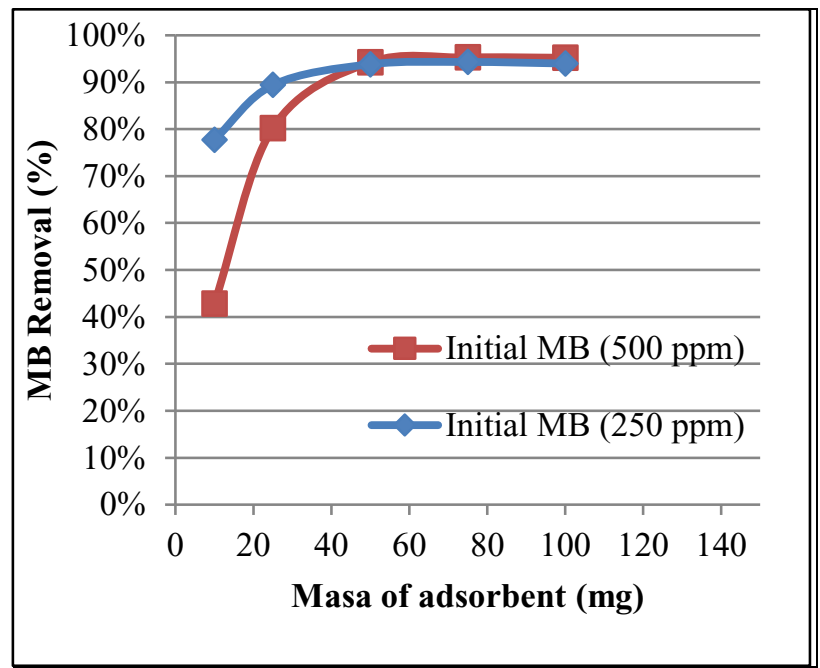

Figure 3.3 Effect of adsorbent mass of adsorption of MB

\subsection{Effect of stirring time on the adsorption of methylene blue}

It was clear from Fig. 3.4 that optimum contact time for removal of $500 \mathrm{ppm}$ of methylene blue was 30 minutes for WHMCA with $94 \%$ of removal efficiency. After 30 minutes of shaking, the increase of methylene blue removal is not significant. This result indicated that the adsorbent reached equilibrium condition in about 30 minutes which is similar to some other adsorbent materials [12] and [13]. Therefore, this adsorbent is suitable for the big scale of wastewater treatment plant considering the energy consumption [5].

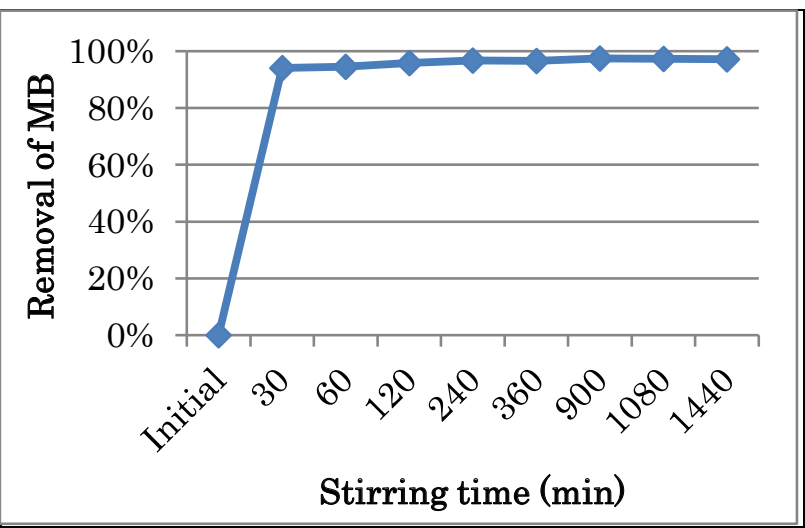

Figure 3.4 Removal of MB in different contact time

\subsection{Effect of $\mathrm{pH}$ on the adsorption of methylene blue}

In adsorption process, $\mathrm{pH}$ is one of the important factors. The $\mathrm{pH}$ of the solution affected the surface charge of the adsorbent, the dissociation of functional groups on the active sites of the adsorbent, and also the structure of the dye molecule [1] and [11]. Fig. 3.5 shows that for methylene blue adsorption, $\mathrm{pH}$ condition does not have a significant influence. This evidence is similar to the previous study [6] where the adsorption of dyes for different $\mathrm{pH}$ resulted in similar adsorption capacity. The lowest removal is at $\mathrm{pH} 2$ because in low $\mathrm{pH}$, the surface of adsorbent is surrounded by hydrogen ion and disturb methylene blue adsorption process [7]. Moreover, the main functional groups in WHMCA used to adsorb methylene blue is carboxyl (COO-). In low pH, carboxyl is protonated into $\mathrm{COOH}$ that have weak adsorption to methylene blue.

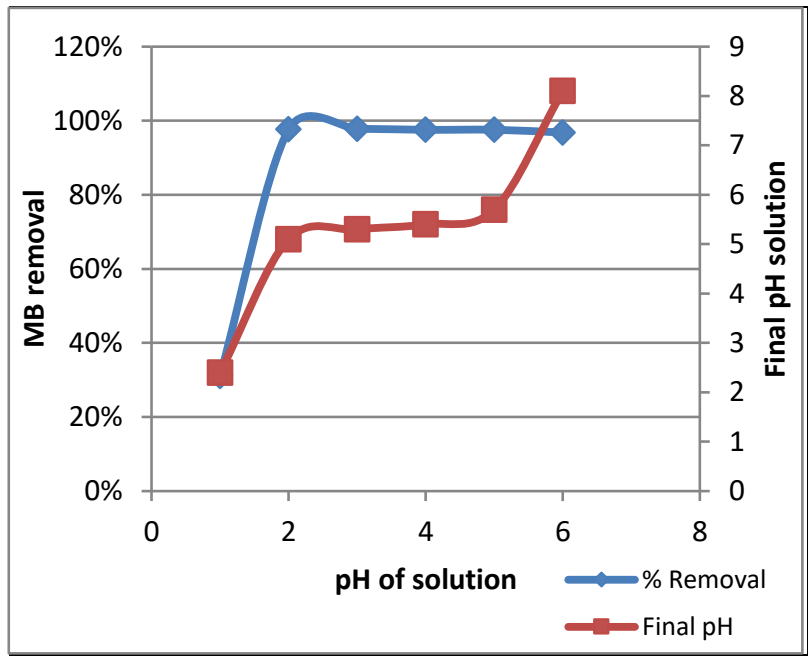

Figure 3.5 Effect of $\mathrm{pH}$ on MB removal

\subsection{Adsorption isotherm}

By various initial concentrations, it could be determined isotherm model for methylene blue adsorption. Langmuir and Freundlich models were applied in order to know adsorption process of methylene blue and the result can be seen from Table 3.1.

Table 3.1. Isoterm Models Between WHP and WHMCA

\begin{tabular}{|l|l|l|l|}
\hline \multirow{2}{*}{$\begin{array}{l}\text { Model } \\
\text { Isoterm }\end{array}$} & Constants & WHP & WHMCA \\
\hline \multirow{3}{*}{ Langmuir } & $\mathrm{K}_{\mathrm{L}}$ & 0,0704 & 0,081 \\
\cline { 2 - 4 } & $\mathrm{q}_{\mathrm{m}}(\mathrm{mg} / \mathrm{g})$ & 261 & 320 \\
\cline { 2 - 4 } & $\mathrm{R}^{2}$ & 0,996 & 0,919 \\
\hline \multirow{3}{*}{ Freundlich } & $\mathrm{K}_{\mathrm{F}}$ & 37,5 & 42,8 \\
\cline { 2 - 4 } & $\mathrm{N}$ & 2,414 & 2,068 \\
\cline { 2 - 4 } & $\mathrm{R}^{2}$ & 0,877 & 0,747 \\
\hline
\end{tabular}

Data shows that the adsorbent is fit to Langmuir model. Negative charge from citric acid in WHMCA will 
bind positive charge of methylene blue, and principally it will make monolayer because of electrostatic repulsion between methylene blue particles and make electrostatic attraction between methylene blue particles and WHMCA. From Table 3.1, it was clear that the maximum capacity of WHMCA is higher than water hyacinth powder without modification (WHP). Data of adsorption capacity (qm) proved that the modification was successfully conducted to increase adsorption capacity.

\section{Conclusion}

Bio adsorbent based on Water hyacinth was successfully modified by citric acid to remove methylene blue in the water. WHMCA showed high adsorption capacity towards methylene blue, with maximum capacity up to $320 \mathrm{mg} / \mathrm{g}$ and fitted with Langmuir model. The presence of some functional groups in the adsorbent is considered as an important factor in the adsorption process. This study proved that citric acid modification in water hyacinth could improve the adsorption capacity of methylene blue in water, therefore the bio adsorbent based on Water hyacinth could be considered as an alternative adsorbent instead of activated carbon.

\section{References}

1. Guo, J., Li, B., Liu, L., and Lv, Kangle. 2014. Removal of Methylene Blue From Aqueous Solution by Chemically Modified Bamboo. Chemosphere 111, pp. 225-231.

2. Zheng, J. C., 2009. Feng, H. M., Lam, M. H. W., Lam, P. K. S., Ding, Y. W., and Yu, H. Q. Removal of Cu(II) in Aqueous Media by Biosorption Using Water Hyacinth Roots as a Biosorbent Material. Journal of Hazardous Materials 171, pp. 780-785.

3. Faisol. A., Afrizal, R. and Sari, S.R. 2008. Preparation of Oil Adsorbent based on Water Hyacinth (Pembuatan Oil Adsorbant dari Eceng Gondok). Jurnal Teknik Kimia, No. 4, Vol. 15. pp. 44-49.

4. Zaman, B. and Sutrisno, E. 2006. Absorption of Amonia by Water Hyacinth in Medical Wastewater (case study of Panti Wilasa Hospital, Semarang) (Kemampuan Penyerapan Eceng Gondok terhadap Amoniak dalam Limbah Rumah Sakit Berdasarkan Umur dan Lama Kontak (Studi Kasus : RS. Panti Wilasa, Semarang). Jurnal PRESIPITASI Vol.1 No.1 pp. 49-54.
5. Siswoyo E, Endo N, Mihara Y and Tanaka S., 2014. Agar-encapsulated adsorbent based on leaf of Platanus sp. to adsorb cadmium ion in water. Water Science and Technology, 70.1, pp. 89-94.

6. Sarioglu, M. and Atay, U. A. 2006. Removal of Methylene Blue by Using Biosolid. Global NEST Journal, Vol. 8, No. 2, pp. 113-120.

7. Han, Runping. 2006. Removal of methylene blue from aqueous solution by chaff in batch mode. Journal of Hazardous Materials B137, pp. 550-557.

8. Reddy, D. H. K., Seshaiah, K., Reddy A. V. R. and Lee, S. M. 2012. Optimization of Cd(II), Cu(III) and Ni(II) Biosorption by Chemically Modified Moringa oleifera Leaves Powder. Carbohydrate Polymers 88, pp. 1077-1086.

9. Li, Z., Teng, T. T., Alkarkhi, A. F. M., Rafatullah, M. and Low, L. W. 2013. Chemical modification of Imperata cylindricaleaf powder for heavy metal ion adsorption. Water Air Soil Pollution 224:1505, pp. 114.

10. Low, K. S., Lee, C. K. and Mak, S. M. 2004. Sorption of copper and lead by citric acid modified wood. Wood Science and Technology 38, pp. 629-640.

11. Siswoyo, E. and Tanaka, S. 2013. Development of eco-adsorbent based on solid waste of paper industry to adsorb cadmium ion in water. Journal of Clean Energy Technology 1 (3), pp. 198-201.

12. Siswoyo, E., Mihara, Y. and Tanaka, S. 2014. Determination of key components and adsorption capacity of a low cost adsorbent based on sludge of drinking water treatment plant to adsorb cadmium ion in water. Applied Clay Science Vol. 97-98. pp. 146152.

13. Siswoyo, E., Firachmatika, A. and Kautsar, R.B. 2016. Removal of $\mathrm{Cu}$ (II) in Water by Using Adsorbent Based on Volcanic Ash of Mount Kelud in Indonesia. International Journal of Environmental Science and Development, Vol. 7 No. 9. pp. 657-660. 